\title{
An Analysis of Sumbawa Language Shift in Tatebal
Village
}

Yomi Septri1, Supriadin ${ }^{2}$

1,2STKIP Paracendekia NW Sumbawa, Nusa Tenggara Barat, Indonesia E-mail:yomiseptri@gmail.com, supriadin1991@gmail.com

\begin{tabular}{|c|c|}
\hline Article Info & Abstract \\
\hline $\begin{array}{l}\text { Article History } \\
\text { Received: } 2021-11-10 \\
\text { Revised: } 2021-11-28 \\
\text { Published: } 2021-12-08\end{array}$ & $\begin{array}{l}\text { This study aims to obtain a types of sumbawa language shift in Sumbawa, especially in } \\
\text { Tatebal village. This study uses a descriptive qualitative method which aims to provide } \\
\text { an overview of the various types of sumbawa language shift in Sumbawa, especially in } \\
\text { Tatebal village. In collecting data, the researcher used direct observation techniques } \\
\text { and interviews with Tatebal society. Observation used to know the way of teenagers, } \\
\text { adults and old people in Tatebal village during doing a daily conversation. Interviews } \\
\text { were conducted with teenagers, adult and old people in the village and interviews with } \\
\text { informants,to add information to the research. Based on the research, the sumbawa } \\
\text { language shift that occured in Tatebal village very diverse, for example the word } \\
\text { maming to adress their father became bapak, mambo became sendal, jelaja became } \\
\text { jendela etc. }\end{array}$ \\
\hline Artikel Info & Abstrak \\
\hline $\begin{array}{l}\text { Sejarah Artikel } \\
\text { Diterima: } 2021-11-10 \\
\text { Direvisi: } 2021-11-28 \\
\text { Dipublikasi: } 2021-12-08\end{array}$ & $\begin{array}{l}\text { Penelitian ini bertujuan untuk memperoleh deskripsi macam-macam bentuk bahasa } \\
\text { sumbawa yang telah berganti dari waktu ke waktu di Sumbawa khususnya di desa } \\
\text { Tatebal. Penelitian ini menggunakan metode qualitative deskriptif yang bertujuan } \\
\text { untuk memberikan gambaran akan beragamnya macam bahasa sumbawa yang telah } \\
\text { berganti di desa Tatebal. Dalam melakukan pengumpulan data, si peneliti } \\
\text { menggunakan teknik observasi secara langsung, wawancara dengan masyarakat di } \\
\text { desa Tatebal. Observasi dilakukan dengan cara memperhatikan bagaimana masyarakat } \\
\text { muda, dewasa dan tua berkomunikasi di dalam keseharian mereka. Wawancara } \\
\text { dilakukan dengan para remaja, dewasa, dan tua yang ada di desa tersebut dan } \\
\text { wawancara dengan informan yaitu untuk menambah informasi dalam penelitian. } \\
\text { Berdasarkan penelitian, macam macam bahsa sumbawa yang telah berganti di desa } \\
\text { Tatebal sangat beragam, contohnya panggilan maming berubah menjadi bapak, mambo } \\
\text { menjadi sendal, jelaja menjadi jendela dan masih banyak lagi. }\end{array}$ \\
\hline
\end{tabular}

\section{INTRODUCTION}

Technology in the world is getting faster in terms of communications, transactions, etc. Nevertheless, the world is not spared from the main communication tool, namely language. According to Vause (2010), language is the most important tool in communication, and communication almost always takes place within some sort of social context. This is why effective communication requires an understanding and recognition of the connections between a language and the people who use it. In line of Rabiah (2012), explain that language is a communication tool used by everyone in their daily life as a means to convey information and arguments to others.

Based on the definition above, it can be concluded that language has become a fundamental communication tool of life. The link between language and life is very close. With language, humans are able to understand each other, and able to establish good socialization.
Therefore, mastering language should be a fundamental principle in order to be a human who can communicate not only within groups, but also within countries, or even able to speak across country.

When we talk about language, language is closely related to society. Because language is the most important tool in establishing communication, and the actor of communication itself is society. When we study about language and the structure of language, this disciplines automatically include to linguistic category. Furthemore, if we study about language and society, this discipline is called sociolinguistics. Linguistics makes us aware of the structure of language whereas sociolinguistics tells us how someone interact with each other using that structure in everyday situations (Nisa, 2019). When we study sociolinguistics certainly we also study about language change. The language change discusses many brances of language Such as language lost, language maintenence, language death and 
language shift, etc. However this research focused on discussing the language shift.

Language shift is a sociolinguistic phenomenon that occurs due to language contact. Language shift involves the problem of using language by a group of speakers which can cause the shift of one language to another or emergence a new language in people lives. According to Fasold in Agyekum (2010), language shift refers to changes in language use among a community of speakers such as when a community stars to use one language in domains and functions in which its members had previously used another language and a shift in the number of speakers of a language. Whereas, Holmes (2001) stated that language shift generally refers to the process, by which one language displaces another in the linguistic repertoire of a community. A language shift means a shift or displace of one minority language mother tongue to a language of wider society. The other domains in which language shift occurs maybe differ for different individual and different groups, but gradually over time, the language of wider displaces the minority language have shifted or replaced the use of their mother tongue to the use of the dominant language and it usually happens to the younger generation.

As the theory above, the researchers can conclude that language shift can occure when the majority of one community dominantly used the language beside their mother tongue language that kind of behavior can be the bigger cause of the language shift, because one language is the communication tool that can be replace by another language when the communicator do not used it in their daily communication, there are several factors associated to language shift. The most fundamental is bilingualism. Fasold (1984) stated bilingualism can ultimately lead to language shift in a society and is often marked by intergenerational switching of the language. Besides bilingualism, many factors are also responsible for language shift. They are bilingualism, migration, economic and social factor, political factors, and also value and attitude of the language factors. Purba (2013) devined a factors of language shift as follows:

a. Bilingualism

One factor of the language shift is bilingualism. Bilingualism is the use of two languages equally in order to communicate with other people alternatively and it always be a precursors of language shift. Bilinguals may use the language they like. Downes (2005) stated that, a number of factors are involved in whether or not bilingualism leads to language shift. A certain language is gradually like in speech acts, which are associated with majority language for instance religion and education and minority language for instance family and friendship.

b. Migration

The potential factor for language shift to occur among vermoculars is migration that encorurages the use of language of the wider society and the consequent loss in proficiency in the original mother tongue. The city which is lived by multiethnic migrants will be the place of language shift. As Holmes (2001) states migrants are virtually monoligual in their mother tongue, but their children become bilingual, but. Most families eventually shift from using their mother tongue at home to using the nasional language. Because there is a pressure from the wider society to speak the dominant language.For speaking dominant language is regarded as a sign of succesful assimilation in the new environment.

c. Economic and social factors

The social and economic goals of individuals in a community are very important in accounting for the speed of language shift. As Holmes (2001) states that obtaining work is most obvious economic reason for learning another language People need a language to communicate and interact with others. They choose the dominant language which they are fluency to use. By used that language ,they can buid a good communication, By coming to the urban areas and getting better jobs than their ancestors who worked as farmers, many migrants formerly become traders, selling their vegetables, fruits and other consumer items in the markets to increase their families' incomes. That situation demand them to mastering both language, their mother tongue language and nasional language.

\section{d. Political factors}

Many factors are responsible for language shift for example goverment policies concerning language and education. Indonesian language is a common language that used in politics, administration and in every single part of goverment. It is the 
language of legislation, political campaign, national, etc.

\section{e. Attitude and values}

Attitude and values is also a crucial factor that influencing the language shift. Holmes (2002) points out, some aspects contribute language shift is not highly valued of the language, and the language is not a seen as the symbol of ethnic identity. Positive attitudes of speakers supports efforts to use the language, these attitudes help people resist the pressure from the majority group to shift to their language.

This research focused on study about Sumbawa language shift as a part of language change. The research area was focused in Tatebal village. Tatebal village is located in NTB province. Precisely in Sumbawa, Tatebal village can be said fairly village because the distance to reach those village is around $45 \mathrm{~km}$ from Sumbawa city. All of the society of this village use Sumbawa language. However the language that was used by the past or old people in Tatebal village began to change from time to time. Or even loss due to the absence of users in using the language it self. For example, the language used by old society in Tatebal village "Maming" to addres father. The word maming is the most polite term to addres a father for his children or the other teenagers. It is also used to respect him. As can be read in the word as in the sentence bellow:

\section{"Me Lako Sia Maming (were will you go father?)"}

In past, people usually used this word by a slight bowed their heads as a tribute to their father. However today it has been replaced with the usual words that we often hear among teenagers, where people tend to call their father as Bapak (father). This exquisite language is very difficult to find among children or teenager today. Because the teenagers in Tatebal village thought the word maming is unsuitable to use anymore for calling their father, it's really old and not suitable to occure in this era. They never met anyone of their age or even around them using the word maming to call their father. Therefore they felt those language (old language) was not important and would not be used again, this reason made them decided to never learn it.

Based on the illustration above, this study aimed to investigate the Sumbawa language shift in Tatebal village, and to know the causes why the teenagers are not really exited to learn and use their old language as the pure language of
Sumbawa. This study assumed that by using old language of Tatebal village the teenagers will more polite to the old people because implicitly the old language of sumbawanese can divide one word into several meaning. This study tries to convince the teenagers, to use the old language that used by people in the past. Because it is still suitable for them even they use it in this globalization era.

\section{METHOD}

Based on the problems that have been formulated in this study, the researcher used qualitative descriptive method to analyse the data. This method directly presents the nature of the relationship between researcher and respondent, and also this method is more specific and able to adapt to the many sharpening of the joint influence and to the value patterns faced. According to Sukidin and Sugiyono (2013), the qualitative method is a method that can produce descriptive data in the form of speech or writing and people behavior that is being observed. Through qualitative research, researchers can recognize subjects and able to feel subject experience in their daily life.

1. The participant of this research are communities of Tatebal village. All the participants are the native speakers of sumbawanese language. The researcher use purposive sampling technique in classifying the participants. The number of participants in this research consist of 6 person. The researcher classifies the participants into several varieties of age from older, adult, and younger.

2. Place and Time of the Research

This research took a place in Sumbawa area, especially in Tatebal village, Lenangguar subdistrict, Sumbawa regency. This research focused on the analysis of Sumbawa language shift that used by Sumbawa comunity in Tatebal village. While this research was took time for one year since September 2020 until Juli 2021.

3. Procedures of Collecting Data

In doing this research, there were several steps that used by the researcher for collecting the data such as, observation, interview, and recording. The first step is the researcher observed the object of the research to find out the faundamental problem. The second step is interview, the third step is the researcher use recording when the researcher doing a conversation with interviewees, the last is note taking. 
4. Data Analysis

This study has three techniques in order to prosessing the data such as : 1 . Data reduction, where the researcher classifying the data related to sumbawanese language shift in Tatebal village into the tables, disposing of unnecessary data, focus in the important data. 2. Data display, the Tatebal village. The last is making explanation by describing the table. 3. Drawing conclusions and verifications, the data concluded base on the two research questions.

\section{FINDINGS AND DISCUSSION}

The research findings in this research included the observation and interview activities about the types and factors of Sumbawa language shift in Tatebal village

A. The Types Of Sumbawa Language Shift In Tatebal Village

Through observation and interview, the participants in Tatebal village were asked to provide about the Sumbawa Language that already shift in Tatebal village. All participant gave their respective responses reasons and experiences about it.The researcher asked to teenager, adults, and old participants about what are types of Sumbawa language shift in Tatebaal village. The researchers devided the sumbawanese language that already shift in Tatebal village into three class of word category, such as noun, adjective, and verbs as listed in the data below:

1) Noun category

\begin{tabular}{|c|c|c|c|c|}
\hline No & $\mathbf{P}$ & $\begin{array}{c}\text { Langua } \\
\text { ge Shift } \\
\text { Types }\end{array}$ & Shift into & Meaning \\
\hline 1 & OP.1 & Mambo & Sendal & Slippers \\
\hline 2 & OP.1 & Jelaja & Jendela & Window \\
\hline 3 & OP.1 & Pet & Topi & Hat \\
\hline 4 & OP.1 & Kedera & Kursi & Chair \\
\hline 5 & OP.1 & Panyak & $\begin{array}{c}\text { Selimar/pant } \\
\text { ar }\end{array}$ & $\begin{array}{c}\text { Bamboo } \\
\text { table/bambo } \\
\text { o bale bale }\end{array}$ \\
\hline 6 & A. 1 & Bilik & $\begin{array}{c}\text { Kamar } \\
\text { (kamar tidur) }\end{array}$ & Bedroom \\
\hline 7 & A. 1 & Jentera & $\begin{array}{c}\text { Kincir } \\
\text { (mainan } \\
\text { anak-anak) }\end{array}$ & Pinwheel \\
\hline 8 & A.1 & Jering & Sisi /ndeng & Side \\
\hline 9 & A. 1 & Ngungis & $\begin{array}{l}\text { Muka (untuk } \\
\text { hewan) }\end{array}$ & $\begin{array}{l}\text { Face (for the } \\
\text { animal) }\end{array}$ \\
\hline 10 & A.1 & Dila & $\begin{array}{l}\text { Lampu (dari } \\
\text { sumbu) }\end{array}$ & Lamp \\
\hline
\end{tabular}

In the table above, there are types of sumbawa language shift in noun category of Tatebal village. The sentences bellow are the examples between past and present language usage:

a. Mambo sai de mu kenang nan ?

(old language)

Sendal sai de mu kenang nan?

(present language)

[who's slippers that you wear?]

b. Sengaro buka jelaja kadu.

(old language)

Sengaro buka jendela kadu.

(present language)

[please open the window.]

c. Na no mu kenang pet, apa panas ano.

(old language)

Na no mu kenang topi, apa panas ano.

(present language)

[you have to wear a hat, because the weather is hot.]

d. Kedera ta tawa datu.

(old language)

Kursi ta tawa datu.

(present language)

[This chair belongs to the king.]

e. Sengaro angkit panyak ana.

(old language)

Sengaro angkit selimar ana.

(present language)

[Please carry the bamboo table.]

f. Tunung pang dalam bilik mu.

(old language)

Tunung pang dalam kamar mu.

(present language)

[Sleep in your room.]

g. Balong jentera nan pe.

(old language)

Balong kincir nan pe.

(present language)

[That pinwheel is great.]

h. Puli patis pang jering berang sampi ana.

(old language)

Puli patis pang sisi berang sampi ana.

(present language)

[The cow stayed beside the river.]

i. Gita nyelong ngungis jaran ana.

(old language)

Gita nyelong muka jaran ana.

(present language)

[Behold, the horse's face is visible.]

j. Jelit dila nan kadu adi.

(old language)

Jelit lampu nan kadu adi.

(present language)

[Sister, please burn the lamp.] 
2) Adjective category

\begin{tabular}{ccccc}
\hline No & P & $\begin{array}{c}\text { Languag } \\
\text { e Shift } \\
\text { Types }\end{array}$ & Shift into & Meaning \\
\hline 1 & OP.2 & Aco' & Sombong & Arrogant \\
\hline 2 & OP.2 & Gemporo & Kemeri & Happy \\
\hline 3 & OP.2 & Baring & $\begin{array}{c}\text { Ngka adil } \\
\text { dzalim/tida } \\
\text { k adil) }\end{array}$ & Wrongdoers \\
\hline 4 & OP.2 & Reno' & Angat & Warm \\
\hline 5 & OP.2 & Peras & Pendek & Short \\
\hline 6 & A.2 & Patitua & Mati/taat & Obedient \\
\hline 7 & A.2 & Be.bar & Gebar/Kekar & Sturdy \\
\hline 8 & A.2 & Longga & Tingi & High \\
\hline 9 & A.2 & Kemuru & Cemburu & Jealous \\
\hline 10 & A.2 & Krao & Tomas & Noisy \\
\hline & & & &
\end{tabular}

In the table above, there are types of sumbawa language shift in adjective category of Tatebal village. The sentences bellow are the examples between past and present language usage:

a. Nya nan keras lalo aco'.

(old language)

Nya nan keras lalo sombong.

(present language)

[He is so arrogant.]

b. Puli gemporo diri ana.

(old language)

Puli geras kemeri diri ana.

(present language)

[He is so happy.]

Lamen dadi tau loka noroa tu baring.

(old language)

Lamen dadi tau loka noroa no tu adil.

(present language)

[If you are a parents, you are not suppose to wrongdoers]

c. Nyaman tu maneng ke ai de masi reno' kuku. (old language)

Nyaman tu maneng ke ai de masi angat kuku.

(present language)

[Taking a shower with a warm water is so confortable.]

d. Peras puin nyir ana.

(old language)

Pere puin nyir ana.

(present language)

[That coconut tree is short]

e. Patitua lamen anak diri ana.

(old language)

Mati' lamen anak diri ana.

(present language)

[His son is so obedient]

f. Diri nan be.bar perana.

(old language)

Diri nan kekar perana. (present language)

[His body is sturdy]

g. Merang longga anak diri ana.

(old language)

Merang tingi anak diri ana.

(present language)

[His son is high]

h. Geras kemuru diri ana pe.

(old language)

Geras cemburu diri ana pe.

(present language)

[He is so jealous]

i. Najina krao lalo kadu.

(old language)

Najina tomas lalo kadu.

(present language)

[Don't so noisy]

3) Verb category

\begin{tabular}{ccccc} 
No & P & $\begin{array}{c}\text { Langua } \\
\text { ge Shift } \\
\text { Types }\end{array}$ & Shift into & Meaning \\
\hline 1 & OP.1 & Balio & Besengal & Fight \\
\hline 2 & OP.1 & Bakenya & Bekati & Joke \\
\hline 3 & OP.1 & Beme & $\begin{array}{c}\text { Ajak/ } \\
\text { tulung }\end{array}$ & Help \\
\hline 4 & OP.2 & Janto' & Jemit & Take A bit \\
\hline 5 & OP.2 & Dondo & Alok & Persuade \\
\hline 6 & A.1 & Guba & $\begin{array}{c}\text { Pukil } \\
\text { keras/ oe' }\end{array}$ & $\begin{array}{c}\text { Hit/hit hard } \\
\text { Jampang }\end{array}$ \\
\hline 7 & A.1 & Jatu & Fete \\
\hline 8 & A.1 & Jejal & Tampir & $\begin{array}{c}\text { Cover/cover } \\
\text { up }\end{array}$ \\
\hline 9 & A.2 & $\begin{array}{c}\text { Kasungk } \\
\text { ar }\end{array}$ & $\begin{array}{c}\text { Reba/ruru } \\
\text { /teri }\end{array}$ & $\begin{array}{c}\text { Fall/fall } \\
\text { down }\end{array}$ \\
\hline 10 & A.2 & Katelar & Nyelam. & Sink \\
\hline
\end{tabular}

In the table above, there are types of Sumbawa language shift in verb category of Tatebal village. The sentences bellow are the examples between past and present language usage:

a. Man sama balio kadu.

(old language)

Man sama besengal kadu.

(present language)

[Do not fight]

Man sama bakenya kadu.

(old language)

Man sama bekati kadu.

(present language)

[Do not joking]

b. Sengaro beme tode ta.

(old language)

Sengaro tulung tode ta.

(present language)

[Please help this kid]

c. Janto' tepung nan kadu.

(old language)

Jemit tepung nan kadu. 
(present language)

[take the snack little bit]

d. Ina ka baeng dondo bua roa mangan.

(old language)

Ina ka baeng alok bua roa mangan.

(present language)

[His mom persuade him to eat]

e. Puli seda ya guba lawang leng maming.

(old language)

Puli seda ya pukil lawang bapak.

(present language)

[Dad hit the door really hard]

f. Jatu adimu bau lema mangan.

(old language)

Jampang adi mu bau lema mangan.

(present language)

[Fete your little brother to eat]

g. Jejal bongkang nan ke batu.

(old language)

Tutup bongkang nan ke batu.

(present language)

[Cover that hole with the stone]

h. Kam kasungkar puen kayu ana.

(old language)

Kam reba puen kayu ana.

(present language)

[That tree is fall down]

i. Kam katelar bedis ana pang ai ba.

(old language)

Kam nyelam bedis ana pang ai ba.

(present language)

[The goat already sink]

there were thirty words of sumbawa language shift that occur in Tatebal village as listed in the tables. This thirty words devided into Three category, such as noun category,adjective category, and verb category. Noun category has ten words, such as : mambo, jelaja, pet, kedera, panyak, bilik, jentera, jering, ngungis, and dila. This ten words are the most frequently used in the past by the old people in Tatebal society, while nowdays this ten words shift into another type of words that has a similar meaning. As the example is the word mambo. The word mambo is the most frequently used by Tatebal society in the past. This word used to indicate a slippers in the past. However in this era, Tatebal society dominantly used a word sendal to signify slippers than mambo.

In adjective category also has ten words as listed in table 6.4. Such as : $A c o$, gemporo, baring, reno', peras, patitua, be.bar, longga, kemuru, and krao. This ten words are the most frequently used by the old people of Tatebal society in the past. However, this ten words shifted into another ten words that has a similar meaning. As an example, the word $a c o$ '. The word $a c o^{\prime}$ dominantly used by the old people of Tatebal society in the past. the word $a c o^{\prime}$ used to signify arrogance in the past. However, nowdays the word $a c o^{\prime}$ shifted into word sombong to indicate arrogance. The word sombong is the most frequently use nowdays by Tatebal society than $a c o^{\prime}$.

In verb category also has ten words as listed in table, Such as: balio, bakenya, beme, janto', dondo, guba, jatu, jejal, kasungkar, and katelar. This ten words are the most frequently used by the old people of Tatebal society in the past. However, this ten words shifted into another ten words that has a similar meaning. As an example is the word balio. The word balio dominantly used by the old people of Tatebal society in the past. The word balio used to signify a fight in the past. However, nowdays the word balio shifted into a word besengal to indicate a fight. The word besengal is the most frequently use nowdays by Tatebal society than balio.

B. Factors that Influence Sumbawa Language Shift in Tatebal Village.

Based on the results of research, several factors can affect language shifts. These factors are also the reason why language can shift. However the factors that caused a language shift occured in Tatebal village are tottaly different from a common factors that causes a language shift in general. Furthemore, there were three factors that cause a Sumbawa language shift in Tatebal villlage. Such as education factor, changing generation factor, and modern factor.

1) Education factor

Education become one of the biggest factor that can influence a shift of Sumbawa language. It cause of all schools nowdays, have aplied a national language as a language used in the schools. Starting from elementary school till a high school. This regulation makes a teenager much more used a national language to communicate with a society. It can impact a Sumbawa language old replace to a loan language from Indonesian language. 
Sumbawanese language not only shift by school regulation. Sumbaawa language can also shift by a social relationship within the scope of the school. As an example, the word muka is most frequently used nowdays that ngungis. these language is a loan language from indonesian language that cause by education.

2) Changing generation factor

Besides education factor, changing generation also become the biggest factor that cause a Sumbawa language shift occured in Tatebal village. That happened because the generation nowdays begin to leave their genuin language. They thought that, their old language is not suitable anymore to used by them (new generation). Nowdays generation of Tatebal village were more often used a loan language to construc their communication. They often used a languaege that mixed whith another language. Such as Indonesian language, Arab language, and English language. As an example, they said "sate ku tidur nong" the word tidur in this sentence was taken from Indonesian language. In another example, they said " $t a$ aku OTW ta naki" the word OTW in this sentence, was an acronim taken from English language wich has meaning [on the way]. The Tatebal young generation nowdays, have felt confortable using a Sumbawa language that have mixed with another language. They don't relize that this kind of behavior can replace or even eliminate their genuin language.

3) Modern factor

In this era, modern era also greatly influence a shift of sumbawa language in Tatebal village. Because nowdays young generation began to use a slang language that they have learned from many mainstream media that borned by modern era. As an example, many children or even teenagers of Tatebal village said "otw" to signify they are on their way. This is one of many term that caused by a modern factor. On the other hand, modern factor was a main factor that born another factor of language shift that occur in Tatebal village. In a modern era, the education more frequently upgrade in every aspeks than before. It is included a language used inside the school. Because of the modern era, the young generation of Tatebal village began to use a loan language. That the reason why modern era become a main factor of Sumbawa language shift in Tatebal village.

\section{CONCLUSIONS AND SUGGESTIONS}

\section{A. Conclusions}

Based on the results of the analysis of this study, there are two conclusions that can be taken in this research: Firstly, the researchers found thirty types of Sumbawa language shift that occur in Tatebal village. It is devided into three category, such as noun category, adjective category, and verb category. The peoples of tatebal village most frequently used the new Sumbawa language than the old language. They argue that the old language is not suitable anymore for communicate with another people nowdays, Secondly, factors that cause a Sumbawa language shift in Tatebal village are education fator, changing generation factor, and modern factor. There are positive and negative impacts of Sumbawa language shift that occur in Tatebal village. The positive impactss are the society of Tatebal village can communicate with a new community to increase their social status and give advantage as a mean of making a living or increasing economic value. Furthermore, the negative impact that people can make their local language shift into another language, or even they will loss their local language.

\section{B. Suggestions}

After doing the research, there are some suggestions to the next students who wants doing the research relates to sociolinguistics particularly about language shift. This thesis only focuses on Sumbawa language shift that occur in tatebal village, Lenangguar subdistrict, Sumbawa regency. For the further research, the researcher suggests the next researcher to conduct the research of sociolinguistict specially aabout language shift in a wide scope. The next researchers also can use other factors that influence language shift base on the research sites. The researcher also hopes that the next researchers not only focus on sociolinguisticts form that used in communication, but with the different issuessuch as adressing, sumbawanese poetry, etc.

\section{REFERENCES}

Agyyekum, K. K. (2010) Language Shift: A Case Study of Ghana. 
https://www.researchgate.net/publicatio $\underline{\mathrm{n} / 250014808,384}$.

Downes, S. (2005). An Introduction to Konnective Knowledge. 20to, 61.

Holmes, J. 2001. An Introduction to Sociolinguistics. Edinburg: Longman.

Nisa, S. (2019). Sociolinguistics. School of Distance Education, the Englsh and Foreign Languages University.

Purba, R. (2013). An Analysis of Language Shift in Java Language in Medan. Jurnal Mantik Penusa, 2-3
Rabiah, S. (2012). Language as a Tool for Communication and Cultural Reality Discloser. Makassar: INA-Rxiv.

Sugiyono. (2013).Metode Penelitian Kuantitatif, Kualitatif, dan R\&D. Bandung: Alfabeta CV.

Vause, J. S. (2010).What is language. Jurnal Demographic to Economic and Environmental Crises, 150-171. 